\title{
De l'epiteli de ceba a la indagació. Un marc per a construir pràctiques investigadores cap a la Competència Científica.
}

Jordi Domènech-Casal (jdomen44@xtec.cat) Institut Marta Estrada (Granollers) i Grup LIEC, Departament de Didàctica de les Matemàtiques i les Ciències Experimentals, Universitat Autònoma de Barcelona Neus Ruiz (nruiz12@xtec.cat) Institut Marta Estrada (Granollers)

El desenvolupament de les dimensions de la competència científica (conceptual, procedimental i epistèmica) té en els treballs pràctics de laboratori un espai candidat. El desplegament de pràctiques investigadores és complex i requereix de marcs metodològics i suports per dur-lo a terme. S'ha desenvolupat un marc metodològic per al treball estructurat amb pràctiques investigadores $i$ bastides de suport $i$ aplicat en una pràctica sobre biologia cel•lular i microscòpia. El marc metodològic proposa diverses bastides de suport per al treball d'habilitats de raonament científic i una seqüència de treball en 5 etapes que culmina en l'escriptura d'un article científic per part dels alumnes. Es justifiquen i descriuen les diferents etapes $i$ els resultats obtinguts i es comenten dinàmiques clau (oralitat, auto i coavaluació) i l'aportació d'aquest tipus de pràctiques a les tres dimensions de la competència científica.

Paraules clau: Indagació, treballs pràctics, ECBI, bastides didàctiques.

Practical laboratory work is a candidate space to develop the conceptual, procedural and epistemic dimensions of scientific competence. Developing inquiry practices is complex and requires methodologic frames and didactic scaffolds. We have developed a methodologic frame for structured inquiry activities and applied it to an activity on microscopy and cell biology. The proposed frame includes several scaffolds for scientific research processes and follows 5 steps resulting in a Scientific Article written by students from their research. We describe and justify each of these steps and discuss some key dinàmics (oral communication, co- and self-assessment) and the impact of this kind of practices on the three dimensions of the scientific competence.

Paraules clau: Inquiry, practical work, IBSE, Didactic scaffolds

\section{INTRODUCCIÓ.}

Tot i que tradicionalment en l'Ensenyament de les Ciències les pràctiques de laboratori es consideren de manera genèrica un espai en què els alumnes adquireixen habilitats i competència científica, el seu impacte depèn profundament del tipus de pràctiques que s'hi desenvolupen. Les pràctiques de laboratori -o treballs pràctics- es poden classificar segons diversos criteris, essent el més utilitzat el paper que hi desenvolupa l'alumne/a: com a aplicador d'una proposta o com a investiga- dor (Caamaño, 1992, Barolli, et al., 2010, TenreiroVieira i Marqués-Vieira, 2006, Baldaia, 2006, Caamaño, 2014). En relació a l'enfoc pedagògic, es poden classificar les pràctiques de laboratori en tres categories principals: instrumentals, demostratives i investigadores (Besson et al, 2012).

Les pràctiques instrumentals tenen per objectiu l'aprenentatge de tècniques i l'ús d'instruments científics (Ús de la balança, lupa binocular...) mentre les pràctiques demostratives es basen en la reproducció per part de l'alumne d'una sèrie de passos tancats amb l'objectiu de comprovar o 
il•lustrar un fenomen o model científic conegut prèviament (Dissecció de cor, observació de bacteris del iogurt,etc.).

Si bé existeix una certa tendència a considerar les pràctiques "actives" o "manipulatives" més riques competencialment, el cert és que les pràctiques instrumentals i demostratives tenen poc valor competencial, perquè: 1) Les habilitats que promouen són habilitats poc transferibles i amb poc valor fora del laboratori, com ara tarar, enrasar o usar un microscopi; 2) La manipulació d'estris i objectes per si mateixa no interpel•la la construcció i apropiació de models científics ni genera habilitats transferibles; 3) Promouen una visió errònia del coneixement científic, en què els models abstractes són merament "comprovats" i no generats per l'observació, discussió i pensament

En contrast amb les dues tipologies anteriors, en les pràctiques investigadores la pràctica té per objectiu el desenvolupament d'una recerca orientada a respondre una pregunta per a la que no tenim resposta. En aquestes pràctiques, el domini de tècniques $o$ instruments 0 de models científics 0 l'observació de fenòmens no tenen sentit per si mateixos, sinó que l'adquireixen en el context d'una recerca, que implica habilitats de raonament científic com dissenyar experiments, formular preguntes o treure conclusions de dades, també anomenades "Inquiry Skills" (Couso, 2014); habilitats més transferibles i, per tant, més competencials

L'OCDE proposa que la Competència Científica es composa de tres dimensions: conceptual, procedimental i epistèmica. La dimensió conceptual inclou els coneixements de ciència i el seu ús, els fets, conceptes, teories i models, i saber aplicar els models científics a contextos reals. La dimensió procedimental s'ocupa de les pràctiques, enfocaments i habilitats de raonament científic (presa i anàlisis de dades, disseny d'experiments) en els que es basa la recerca empírica. Mentre que la dimensió epistèmica s'ocupa de la comprensió del marc lògic i social en què es genera el coneixement científic i la funció que desenvolupen en la Ciència les preguntes, observacions, teories, entre d'altres coses, per a diferenciar el que és ciència del que no ho és (OCDE, 2013; Garrido i Simarro, 2014). Si bé queda clar que determinades "Inquiry Skills" s'ubicarien clarament en la dimensió procedimental, alguns aspectes de les mateixes (com treure conclusions de dades) tindrien també components de la dimensió epistèmica

Als currículums, les "Inquiry Skills" es presenten com a entitat pròpia sota diverses denominacions. "Scientific and Engineering Practices", segons el National Research Council (2012), i en el currícu- lum actual LOMCE (Ministerio de Educación, 2015) encarnades en un bloc comú present a totes les matèries científiques anomenat "Proyecto de Investigación", com a criteris d'avaluació:

1) Planear, aplicar, e integrar las destrezas y habilidades propias de trabajo científico.

2) Elaborar hipótesis, y contrastarlas a través de la experimentación o la observación y argumentación.

3) Discriminar y decidir sobre las fuentes de información y los métodos empleados para su obtención.

4) Participar, valorar y respetar el trabajo individual y en grupo.

5) Presentar y defender en público el proyecto de investigación realizado.

En el seu desplegament a l'aula, les pràctiques d'indagació en què es reprodueixen els passos del procés de creació del coneixement científic (Caamaño, 2002 i 2012) són una oportunitat per al desenvolupament de la competència científica. Tot i això, el seu desplegament a l'aula és encara lent, ja que per al professorat suposa un xoc amb concepcions pròpies sobre la ciència (Caamaño, 1992) i impliquen la necessitar d'elaborar eines i marcs didàctics cap a l'autonomia en l'activitat investigadora de l'alumnat. Una crítica que reben en ocasions determinades accepcions de la indagació (molt centrades en les dimensions procedimental i epistèmica) és la dificultat de connectar la pràctica investigadora amb conceptes científics clau i, en el seu ús extensiu, la dificultat de generar un marc de models científics globals on ubicar els fenòmens (Viennot, 2011). Aquesta manca d'eines i marcs didàctics dificulta el pas a pràctiques més investigadores, el que suposa un dèficit metodològic

L'objectiu d'aquest article és transformar una pràctica convencional en una pràctica investigadora i, en el procés: 1) Proposar un marc metodològic per a seqüenciar pràctiques investigadores; 2) Testar i proposar bastides i elements de suport per a l'alumnat per a dur a terme amb èxit pràctiques investigadores; 3) Analitzar l'aportació de les pràctiques investigadores a les tres dimensions de la Competència Científica.

\section{DISSENY DE LA PROPOSTA.}

Hem partit de la proposta d'Ensenyament de les Ciències Basat en la Indagació (ECBI) que proposa seqüenciar el treball investigador seguint l'itinerari natural que prenen en la resolució d'una pregunta o recerca (Osborne i Dillon, 2008; Caamaño, 2012, Llewellyn, 2005), estructurant-se en diverses etapes: 1) Formular preguntes investigables; 2) Donar 
prioritat a les proves i l'experimentació; 3) Analitzar les proves; 4) Formular una explicació basada en les proves; 5) Connectar l'explicació amb el coneixement científic 6) Comunicar i justificar l'explicació 7) Reflexionar sobre el procés i aprenentatge.

A partir d'aquesta proposta inicial hem creat un marc metodològic format per una seqüència en diverses etapes, i diverses bastides didàctiques, disponibles a la web del ProjecteC3 [1]. S'ha pres com a punt de partida de dues pràctiques instrumentalsdemostratives cèlebres als centres educatius de primària i secundària: l'observació mitjançant microscopi l'epiteli de ceba i l'observació de cèl•lules de mucosa bucal i s'han transformat en una pràctica investigadora, estructurada [2], per tal que pugui servir de bastida perquè els alumnes més endavant duguin a terme investigacions obertes.

En la pràctica investigadora resultant, de 10 hores de durada -dissenyada i duta a terme amb 59 alumnes de 1r d'ESO de l'Institut Marta Estrada de Granollers- els alumnes condueixen una recerca repartits en equips de 3 alumnes i la conclouen amb l'escriptura i publicació d'un article científic. Els/les alumnes formulen una pregunta d'investigació dins un marc experimental semi-obert (observació de cèl•lules al microscopi, escollint entre diverses mostres). Descrivim a continuació les diferents etapes de la seqüència, incloent per a cada etapa la seva justificació, les bastides didàctiques i les observacions en la seva aplicació.

\section{Etapa 1 (2h). Presentar un context i formular i transformar preguntes en investigables.}

Formular preguntes investigables és una activitat escolar que afronta dues dificultats: el context i models inicials i la "investigabilitat" de les preguntes

Pel que fa al context i models inicials quan demanem als alumnes que es formulin preguntes sense oferir-los un context o situació de partida, creem una fal•làcia. Els científics no "inventen" preguntes del no-res, sinó que les formulen davant una sèrie d'evidències que mostren contradiccions, semblances entre si o en relació amb altres fenòmens i models previs. Per tant, si volem que els nostres alumnes es plantegin preguntes cal que els proposem un context o conjunt inicial de fenòmens, objectes, elements a partir dels quals puguin formular-les i fem emergir o aportem uns models explicatius inicials, que o bé hi entrin en conflicte o bé permetin intentar donar sentit a les proves (Merino i Izquierdo, 2011, Sanmartí i Márquez, 2012).
Si veig que "surt aigua de terra", em puc preguntar d'on ve, perquè surt uns dies i no uns altres, si és potable, $i$ formular fins $i$ tot hipòtesis inicials com ara si es tracta d'una fuita, o si és un esdeveniment tectònic, "en base als meus models inicials de lampisteria, aqüífers i tectònica de plaques". Però no podré preguntar-me res si no veig que surt aigua i si no sé prèviament absolutament res sobre l’aigua.

Pel que fa a la "investigabilitat" de les preguntes, no totes les preguntes són investigables experimentalment. Les preguntes que comencen per "Perquè" o "Com" no són investigables, perquè en realitat interpel•len quins són els models abstractes que regeixen un fenomen. Com que els models abstractes no són mai observables empíricament, aquestes preguntes no són útils per a dissenyar recerques o experiments (Domènech-Casal, 2014). Una manera de transformar aquestes preguntes no investigables en investigables és dirigir-les a les variables que participen en el fenomen. Les preguntes que comencen per "Fa alguna diferència si..." o "Què passa si..." són investigables: no es dirigeixen al model que regeix un sistema, sinó als efectes de les seves variables, que sí són observables, i per tant, susceptibles de ser observades i experimentades per a construir un model. Si bé les preguntes no investigables no permeten iniciar la recerca, adquireixen importància com a espai de discussió prèvia per a la construcció de models hipotètics mitjançant analogies. La formulació de les preguntes investigables porta implícita una hipòtesi inicial explicativa o model a comprovar, basada en la variable d'anàlisi.

\section{Pregunta no investigable:}

- Perquè surt aigua uns dies i no uns altres? Preguntes investigables:

- Fa alguna diferència si mesurem si surt aigua en dies freds i en dies càlids? (model implícit: es fon aigua subterrània).

- Què passa si tanquem i obrim les claus de pas del veïnat? (model implícit: hi ha una fuga d'aigua).

- Quina diferència hi ha entre el contingut d'aigua que surt i la de l'aixeta?(model implícit: esdeveniment tectònic que duu aigua de mar o subterrània).

Per tot això, els primers passos d'una pràctica investigadora han de preveure acompanyar els alumnes en la formulació de preguntes investigables i preveure un context (evidències i models previs) i itinerari de reformulació de les preguntes. 


\section{PRESENTACIÓ DEL CONTEXT i MODELS INICIALS}

Com a context, s'han aportar diverses mostres de partida, i s'ha descrit als alumnes el model inicial de la cèl·lula, com a base de la vida en tots els éssers vius:

- Tots els éssers vius són fets de cèl·lules, alguns són unicel|lulars i d'altres pluricel|lulars.

- Les cèlllules poden tenir diferents formes i funcions i són observables i caracteritzables al microscopi.

- Tots els éssers vius s'alimenten (autòtrofs/heteròtrofs) i es reprodueixen.

- $\quad$ Alguns éssers vius, com els bacteris, ens serveixen per a fabricar aliments (iogurts), d'altres són perjudicials.

S'han proposat als alumnes diverses mostres de partida:

- Un tros de formatge en el que hi havien crescut bacteris.

- Un tros de carn en el que hi havien crescut fongs (negres).

- Un tros de verdura en el que hi havien crescut fongs (vermells).

- Un iogurt.

- Epiteli de ceba.

- Mucosa bucal

- Etc.

\section{FORMULACIÓ I TRANSFORMACIÓ EN PREGUNTES INVESTIGABLES}

En el procés de formulació de les preguntes, es va demanar als alumnes que proposessin quines preguntes els suggerien les mostres, tenint present que podrien fer servir microscopi per a resoldre-les. Es va proposar als alumnes re-formular les seves primeres preguntes usant els iniciadors de preguntes investigables ("Fa alguna diferència si",...), seguint la següent estructura Context-Pregunta-Model (però no necessàriament aquest ordre):

- Context i model inicial: Com que sabem que...(fenòmens, models inicials i observacions previs)

- Pregunta: Ens preguntem si Fa alguna diferència si....? (pregunta investigable)

- Model: Això ens permetrà comprovar si... (hipòtesi o model implícit).

La formulació de preguntes es va dur a terme, en primer lloc deixant temps als equips de 3-4 alumnes per a formular la seva pregunta inicial, per després proposar-los els tres iniciadors per a formular la seva pregunta investigable seguint la pauta en tres apartats, que va ser discutida de manera oral i informal a l'aula, millorada i anotada. Alguns exemples de preguntes generades:

\begin{tabular}{|c|c|c|c|}
\hline & Pregunta 1 & Pregunta 2 & Pregunta 3 \\
\hline $\begin{array}{l}\text { Context i model inicial. } \\
\text { Com que sabem que.... } \\
\text { Perquè...? Com...? } \\
\text { (Fenòmens, models i ob- } \\
\text { servacions previs. Pregunta } \\
\text { no investigable). }\end{array}$ & $\begin{array}{l}\text { Tots els éssers vius estem fets de } \\
\text { cèl-lules. Els éssers vius tenim mi- } \\
\text { des diverses. Perquè alguns és- } \\
\text { sers vius som més grans que al- } \\
\text { tres? }\end{array}$ & $\begin{array}{l}\text { Les parts de la cèl·lula serveixen per } \\
\text { diferents funcions. Els bacteris són } \\
\text { útils per a elaborar aliments i també } \\
\text { els fan malbé o podreixen. Perquè } \\
\text { els bacteris de vegades són útils i de } \\
\text { vegades fan malbé? }\end{array}$ & $\begin{array}{l}\text { Cada ésser viu té òrgans di- } \\
\text { ferents per alimentar-se de } \\
\text { coses diferents. Els fongs } \\
\text { són heteròtrofs i s'alimenten } \\
\text { d'aliments molt diversos, tant } \\
\text { vegetals com animals. Com } \\
\text { mengen els fongs? }\end{array}$ \\
\hline $\begin{array}{l}\text { Pregunta. Fa alguna dife- } \\
\text { rència si....? } \\
\text { (Pregunta investigable). }\end{array}$ & $\begin{array}{l}\text { Hi ha diferències en la mida de les } \\
\text { cèl·lules entre organismes grans } i \\
\text { petits? }\end{array}$ & $\begin{array}{l}\text { Hi ha diferències entre la forma i les } \\
\text { parts de les cèl/lules de bacteris útils } \\
\text { i bacteris que podreixen? }\end{array}$ & $\begin{array}{l}\text { Hi ha diferències entre la } \\
\text { forma } i \text { les parts de les } \\
\text { cèl/lules de fongs segons } \\
\text { què mengen? }\end{array}$ \\
\hline $\begin{array}{l}\text { Model. Això ens permetrà } \\
\text { comprovar si... } \\
\text { (Model implícit). }\end{array}$ & $\begin{array}{l}\text { Els éssers vius més grans ho són } \\
\text { perquè tenen cèl/lules més grans. }\end{array}$ & $\begin{array}{l}\text { Hi ha parts de la cèlllula que facin } \\
\text { que un bacteri sigui útil o faci malbé } \\
\text { el menjar. }\end{array}$ & $\begin{array}{l}\text { Hi ha alguna cosa de la for- } \\
\text { ma d'una cèlllula que l'ajudi } \\
\text { a alimentar-se d'un aliment o } \\
\text { un altre. }\end{array}$ \\
\hline
\end{tabular}

Taula 1. Presentació del context i models inicials, i formulació i transformació preguntes en investigables. 


\section{Etapa 2 (1h). L’acompanyament en el disseny de l'experiment.}

El disseny d'experiments és una habilitat complexa que implica el domini de conceptes com variable independent, variable depenent, control, etc. que poden resultar complexos per a l'alumnat dels primers cursos de l'ESO. Convé començar el treball amb experiments simples (encara que poc robusts) i discutir després sobre els primers dissenys creats aspectes com rèpliques, controls, etc. Per a iniciar el treball, hi ha dos elements importants: ajudar els alumnes a diferenciar entre què mesurarem (variable depenent) i les mostres que mesurarem (variable independent) i a anticipar els possibles resultats (desenllaços) i què significarien, ja que això els ajuda a connectar el disseny de l'experiment amb la pregunta que volen respondre $\mathrm{i}$ la robustesa de l'experiment. Aquesta és una manera de connectar el plantejament d'hipòtesis amb la manera de comprovar-les.

Es va proposar als alumnes que escollissin quines mostres els calia observar per poder respondre a la seva pregunta investigable, i que completessin una Taula de Desenllaços [3] per ajudar-los a preveure'n la utilitat, seguint esquemes previs (Domènech-Casal, 2013b). En la Taula de desenllaços, els alumnes anoten els possibles desenllaços de l'experiment (les combinacions de resultats possibles) i què significaria cada combinació.

\begin{tabular}{|c|c|c|c|c|}
\hline \multicolumn{5}{|c|}{ DISSENY D'EXPERIMENTS } \\
\hline \multicolumn{5}{|c|}{ En què ens fixarem, què observarem: } \\
\hline $\begin{array}{l}\text { Taula de } \\
\text { Desenllaços }\end{array}$ & Mostra 1 & & Mostra 2 & $\begin{array}{c}\text { Voldria dir } \\
\text { que.... }\end{array}$ \\
\hline Si... & & $i \ldots$ & & \\
\hline Si... & & i... & & \\
\hline Si... & & $i \ldots$ & & \\
\hline
\end{tabular}

En el disseny d'experiments, es va donar importància a que els alumnes tinguessin les mostres davant seu per a poder-s'hi referir, i, de nou, es va promoure la presentació i discussió oral informal dels experiments proposats.

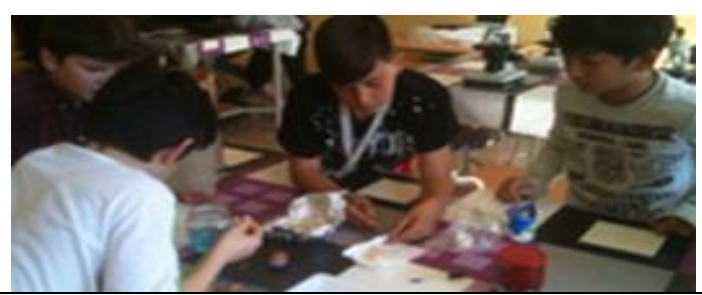

Figura 1a. És important que durant el disseny dels experiments els alumnes tinguin a l'abast les mostres inicials a partir de les quals faran la seva re cerca, amb l'objectiu de facilitar la discussió.

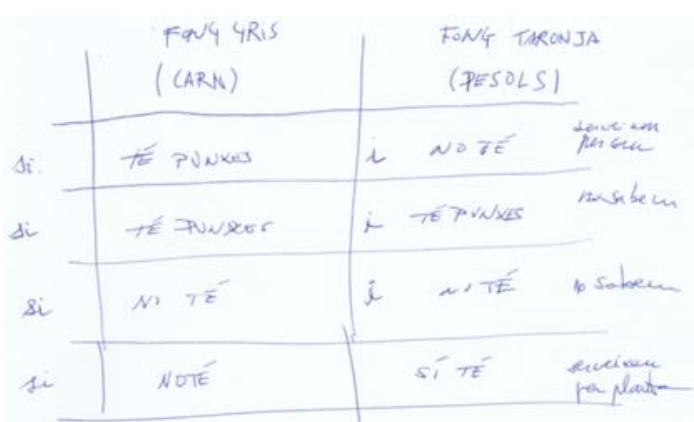

Figura 1b. Exemple de taula de desenllaços produït pels estudiants.

\section{Etapa 3 (3h). El registre i l’anàlisi de dades.}

En el disseny d'experiments, els alumnes solen descuidar paràmetres de mesura que es fan evidents en el moment del registre de dades. Això implica dos aspectes principals:

1) la concreció en els paràmetres de mesura, ja que "Gran" "Petit" "Molt" o "Poc" són termes que han de concretar-se en aquest moment en magnituds i unitats "Diàmetre major de 1,5 cm" o "Menys de 2 grs" ;

2) La variabilitat que apareix en les mesures (diferents camps d'observació en el microscopi, diferents preparacions de la mateixa mostra,...).

Per a poder preparar les mostres, en aquest punt es va fer l'explicació sobre com preparar mostres per al microscopi i com usar-lo. En la recollida de dades, es va mantenir la conversa informal com a manera de que cada equip informés dels seus avenços i problemàtiques:

A-Nosaltres mesurem si són iguals els bacteris del iogurt i els que
degraden.
P-Quants en comparareu?
A-Tots els que es veuen a la mostra...200 o 300.
P-l quan direu si són iguals?
A-Si s'assemblen.
P-En què? Què podeu veure al microscopi?
A-Hem dit que la forma. Si tenen punxes, o pèls.
P-O la mida o el color.
A-Sí, el color també, però mirarem més la forma.
P-I si només s'assemblen alguns de cada i la resta no? Seran
iguals?
A-No.
P-Quan direu que són iguals?
A-Doncs, si la majoria de cada mostra són diferents, direm que són
diferents.
P-Quants són la majoria? Un $60 \%$ ? Un $80 \%$ ?
A-Sí, $80 \%$.
P-Com ho comptareu? Com ho anotareu?




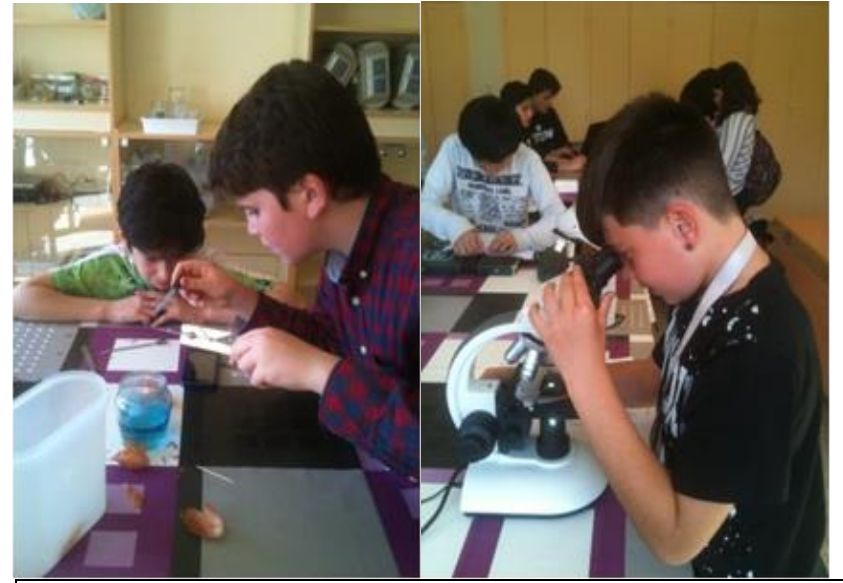

Figura 2. En la recollida de dades els alumnes es troben amb la necessitat de concretar els paràmetres de mesura que hagin quedat sense concretar, una part que conceptualment pertany al disseny d'experiments però que és més eficaç tractar mitjançant la conversa del professor (P) amb els alumnes $(A)$ en el registre de dades.

\section{Etapa 4 (2h). Extreure i comunicar conclusions. La comunicació cientí- fica.}

Diversos autors consideren que orientar les activitats d'indagació a la comunicació incideix positivament en la comprensió del procés (Caamaño, 2002, Menoyo, 2010). En part, perquè les habilitats cognitivo-lingüístiques necessàries per al desenvolupament de raonaments científics (descriure, comparar, justificar, argumentar) van associades al domini de tipologies textuals concretes que es poden ensenyar (Jorba, Gómez i Prat, 1998). El treball d'aquestes tipologies textuals en el marc rellevant dels gèneres lingüístics propis de les ciències (com l'article o pòster científic) pot enfocar-se proporcionant pautes lingüístiques (connectors gramaticals, iniciadors de frase,etc.) i plantilles que estructurin el discurs seguint el procés científic que representen els apartats d'un article científic (Domènech-Casal, 2013b).

Pautes i bastides per la comunicació: Se'ls ha proposat escriure un article científic, proporcionant-los una plantilla d'article científic escolar que contenia iniciadors de frase característics de cada apartat (Introducció, Material i Mètodes, Resultats i Conclusions) [4]. Per a articular el procés d'escriptura, s'ha seguit un acompanyament: l'article no s'ha escrit al final, sinó que en cada etapa de la investigació: cada etapa de la recerca és acompanyada de la redacció de l'esborrany de la secció corresponent de l'article: Etapa 1 (Introducció), Etapa 2 (Material i Mètodes), Etapa 3 (Resul- tats), Etapa 4 (Conclusions). En cada etapa, el professor explica la naturalesa comunicativa de l'apartat corresponent i després deixa $15 \mathrm{~min}$ als alumnes perquè l'elaborin. Es resolen els dubtes, es llegeix i comenta alguna de les produccions en veu alta i es continua l'acompanyament amb el següent apartat, mantenint la comunicació oral no formal a l'aula. En el cas de la formulació de les Conclusions, per ajudar els alumnes a raonar i treure conclusions de les seves dades, en primer lloc s'ha reprès la conversa a l'aula, comentant de manera informal els resultats obtinguts i quines conclusions se'n derivarien. Per a fer-ho, s'ha reprès la Taula de Desenllaços i s'ha reforçat l'ús de connectors gramaticals com "Per tant..." "Així doncs..." o "En conseqüència".
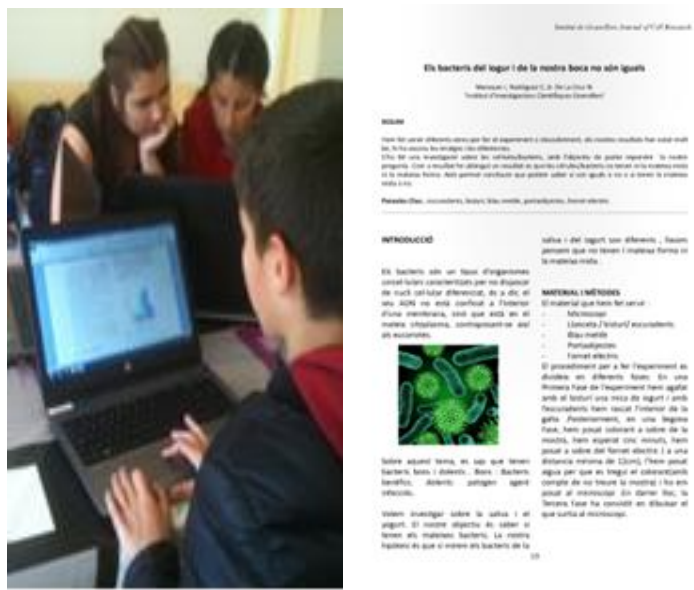

Figura 3: Els articles resultants es van recollir i agrupar en una publicació digital, el Institut de Granollers Journal of Cell Research i són disponibles a: https://issuu.com/jdomenechca/docs/revista

\section{Etapa 5 (2h). L’avaluació i l'autoavaluació.}

Fer que els alumnes participin de manera activa en la seva avaluació i la dels seus companys, és un darrer pas important per diverses raons:

1) l'avaluació és en la piràmide de Bloom (1956) una de les habilitats cognitives més complexes i suposa una apropiació més profunda dels models;

2) avaluar el treball de companys és també una manera d'obtenir una nova mirada sobre la pròpia feina; i

3) fer participar els alumnes en l'avaluació implica aclarir i compartir els criteris d'avaluació, que altrament podrien no haver-se fet explícits

Però per a fer possible l'auto- i co-avaluació cal proporcionar als alumnes suports que permetin avaluar (-se), com ara les rúbriques i llistes de 
comprovació i facilitar que els alumnes refacin les tasques després d'aquesta avaluació.

Eines i dinàmiques per a l'auto i coavaluació: Es van proporcionar a cada equip les còpies en paper dels articles elaborats per tots els equips i se'ls va proporcionar una llista de comprovació [5] per a revisar tots els articles. El professor es movia entre els diferents grups ajudant en la tasca de revisió i comentant amb ells els dubtes. Al final de la sessió, tots els equips rebien una revisió de la seva feina fet per la resta d'equips i tots els alumnes havien comentat entre si i amb el professor dubtes respecte els criteris d'avaluació. Amb aquesta avaluació, els alumnes milloraven els seus articles fins a la versió final que s'ha usat per a elaborar la publicació digital.

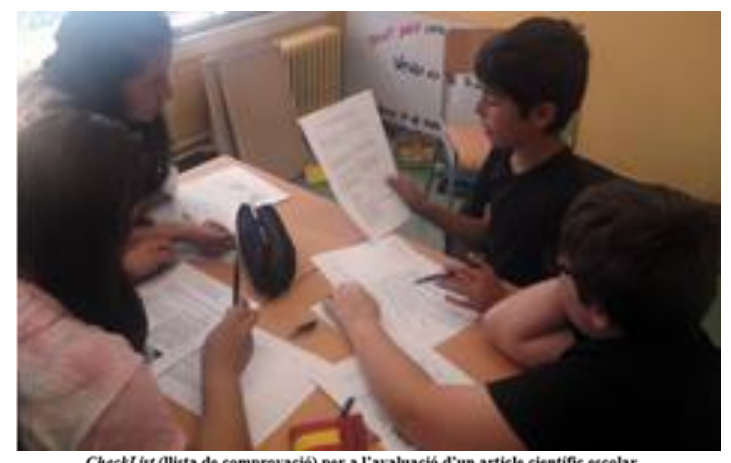

CheckList (llista de comprovació) per a l'avaluació d'un article cientific escolar

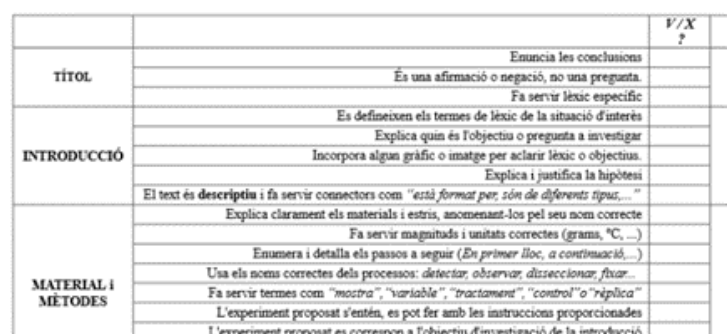

Figura 5: El treball d'avaluació d'articles d'altres companys no només serveix per a adquirir una mirada més crítica sobre el propi treball, sinó que també serveix com espai on trobar exemples o models de com resoldre aspectes comunicatius o de format. En nivells superiors, pot contextualitzar-se en el paper avaluador dels Consells Editorials (Domènech-Casal, 2016b)

L'activitat es va desenvolupar correctament, sense excessives dificultats. Els alumnes ja havien treballat en activitats anteriors el disseny d'experiments i la comunicació en formats científics (Llorente et al, en avaluació, Domènech et al, 2016) i estaven familiaritzats amb alguna de les bastides. Al llarg de l'activitat es van produir situacions particulars que trenquen el concepte lineal d'investigació científica i que creiem que convé explicitar i evidenciar als alumnes: les evidències van generar les preguntes (i no a l'inrevés), i en algun cas, els resultats van fer redefinir els experiments.

L'activitat ha afavorit la participació de tots els alumnes en activitats de raonament complex, com ara el disseny d'experiments o treure conclusions de dades. Els alumnes han tret diverses conclusions: "Els bacteris d'ús alimentari són més grans que els que degraden el menjar" o "Els humans som més grans que les cebes perquè tenim més cè/•/ules" que posteriorment s'han matisat en la conversa a l'aula. Els alumnes han usat en la seva discussió, de manera habitual, termes com "cèl•lula", "procariota", "eucariota", o noms de regnes dels éssers vius, com Fongs o Bacteris.

Els productes parcials (i.e. les taules de desenllaços) i final (article científic) mostren un molt bon nivell en la pràctica investigadora dels alumnes, que atribuïm a les bastides didàctiques (en particular a l'ús intensiu de l'oralitat) i a les dinàmiques d'auto i co-avaluació.

\section{CONCLUSIONS.}

\section{Un marc didàctic per a les pràctiques investigadores.}

La seqüència d'indagació proposada és una seqüència estructurada en 5 passos, i un total de 10 hores que permet que els alumnes posin en pràctica diverses habilitats científiques com formular preguntes investigables, dissenyar experiments, treure conclusions de dades i comunicar científicament. Al llarg de la seqüència els alumnes elaboren diversos productes parcials associats a aquestes habilitats específiques (disseny de la pregunta, disseny de l'experiment, recollida de dades,...) i un producte final, que proporcionen evidències per a l'avaluació d'aquestes habilitats. El fet que l'escriptura de l'article científic es dugui a terme de manera paral•lela a la recerca evidencia la correspondència de cadascuna de les etapes de la seqüència amb el paper que juga cada apartat de l'article en el discurs científic. Considerem que l'estructura proposada, en forma d'indagació estructurada (el professor escull les evidències, tècniques d'anàlisi i models inicials, però deixa obertes les preguntes) permet aplicar de forma sostenible la transformació d'altres pràctiques instrumentals o demostratives en investigadores i pot ser útil a altres docents, i que la seqüència de 5 passos i l'escriptura paral•lela de l'article científic és un marc metodològic útil per aplicar en pràctiques d'altres àmbits temàtics que permetin el disseny d'experiments escolars. Creiem important destacar el paper de l'oralitat en la seqüència, ja que aquesta ha participat en totes les etapes, en què 
s'ha promogut que cada equip comuniqués de manera informal els seus progressos als companys, per a discutir-los entre tots. Ha estat també un espai on el professor ha pogut recollir evidències d'aprenentatge de forma ràpida i senzilla, tal com es proposa en publicacions prèvies (Besson et al, 2015).

\section{Ensenyament i avaluació d’habilitats de raonament científic i bastides lin- güístiques.}

Al llarg de la seqüència, es proposen als alumnes diverses bastides de caràcter lingüístic com a suport per al desenvolupament d'habilitats de raonament científic (Inquiry Skills), entre elles els iniciadors per a la formulació de preguntes investigables, la Taula de desenllaços i la plantilla d'article científic amb iniciadors de frase [6]. Aquestes bastides han estat de molta utilitat tant des del punt de vista de l'aprenentatge com a l'auto i co-avaluació, i és important destacar que el seu ús necessita d'una certa demostració per part del professor: els alumnes han de "veure" el professor usant-les per a poder-les usar ells. Tot i que no és objecte d'aquest article, s'han desenvolupat també al final de l'activitat preguntes d'examen dirigides a avaluar "Inquiry Skills" específiques: raonament inductiu (treure conclusions de dades), raonament deductiu (fer prediccions a partir d'un model) disseny i avaluació d'experiments, i construir i identificar preguntes científiques, seguint propostes anteriors (Goytia et al, 2015b) que pensem que poden ser d'utilitat per al lector.

\section{Pràctiques investigadores per a la Competència Científica.}

Tot i que l'activitat s'estructura seguint etapes corresponents a les diverses "Inquiry Skills", molt vinculades a la dimensió procedimental, l'activitat aconsegueix desplegar també aspectes de les dimensions conceptual i epistèmica. El treball des de models i contexts inicials per a generar preguntes i la redacció i discussió final de les conclusions són elements de l'activitat que es vinculen de manera forta a models científics i dinàmiques de creació de coneixement concret (dimensions conceptual i epistèmica), com analitzem a la Figura 6.

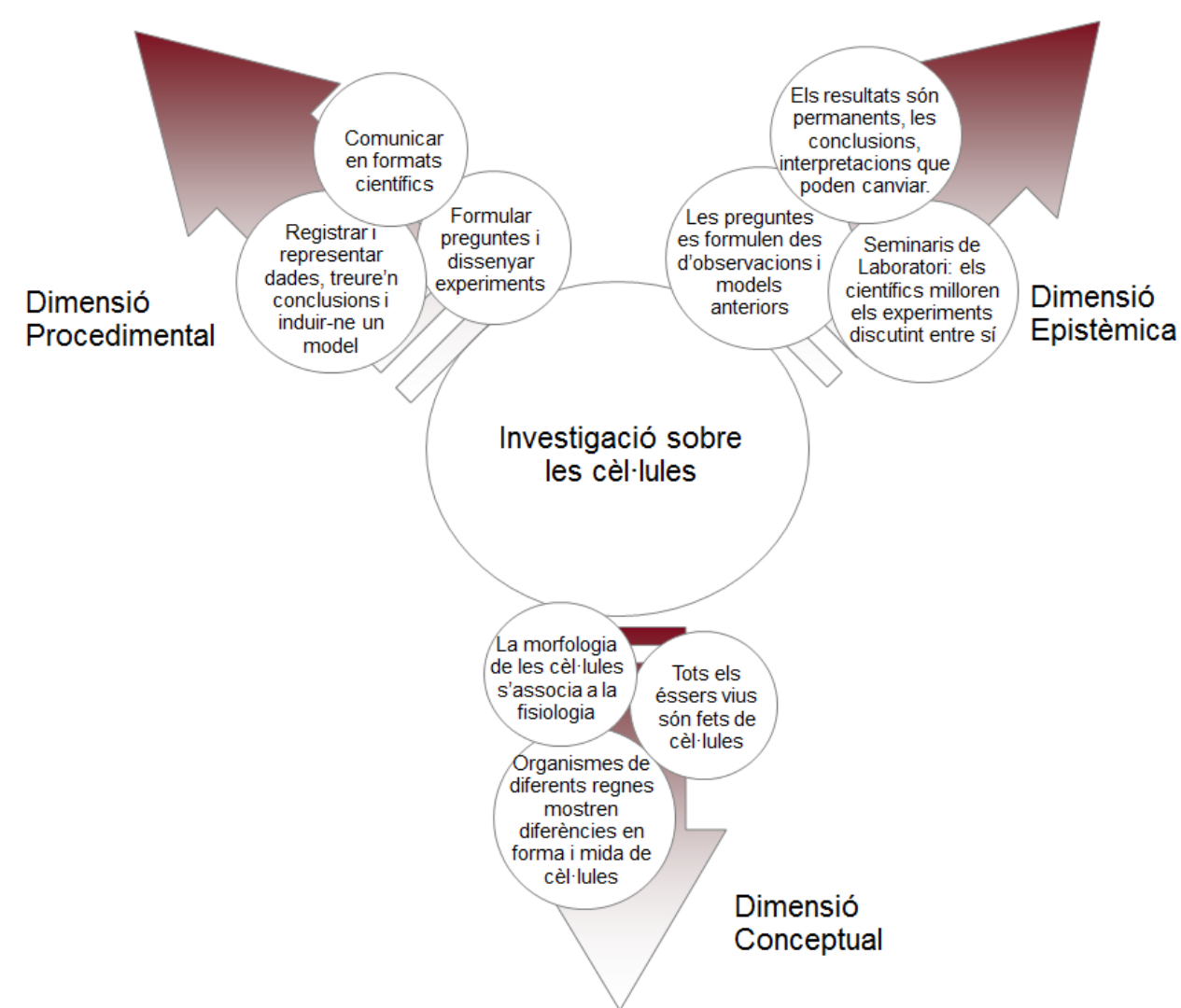

Figura 6: Esquema - resum de les aportacions a les diferents dimensions de la competència científica. L'ús d'aquest esquema en construir l'activitat ha permès evidenciar la necessitat d'esdeveniments epistèmics (com la discussió oral o la síntesi final) i models científics inicials que cal oferir com a context. 
En particular, pensem que per al treball de la dimensió conceptual és fonamental el treball inicial amb el context i models inicials, i fer atenció a l'ús apropiat del lèxic científic durant les converses a l'aula, amb l'ús de referents d'aula com llistats de lèxic associats a imatges visibles durant l'activitat. Aquest impacte en les diferents dimensions ens fa pensar que el marc metodològic proposat per a les pràctiques investigadores (partir d'uns models i evidències tancats i acompanyar la formulació de preguntes i desenvolupament de la recerca) és una proposta útil i adaptable per al treball en altres temes diferents de la cèlılula, i és especialment útil per als alumnes que hauran de desenvolupar com a part de la seva educació secundària un treball de recerca, que és freqüent que els alumnes arribin a aquesta etapa de la seva formació sense haver dut a terme mai cap recerca estructurada, ni indagacions tancades.

Aquest marc metodològic s'inscriu en el treball en el desenvolupament de la competència científica que es duu a terme a l'Institut Marta Estrada (Granollers). Els lectors interessats a desenvolupar pràctiques investigadores estan convidats a compartir-les a l'espai col•laboratiu de pràctiques de laboratori EduWikiLab [7], que hi dedica una secció específica (Besson et al, 2012).

\section{AGRAIIMENTS.}

Els autors agraeixen a la comunitat educativa de I'Institut Marta Estrada (alumnes, professorat i famílies) el seu recolzament en el desenvolupament l'aplicació dels marcs metodològics proposats i al grup de treball EduWikiLab i el Projecte C3 les bases pedagògiques i recursos didàctics. Agraïm també al CESIRE del Departament d'Ensenyament el préstec de microscopis per a poder dur a terme l'activitat. Reflexions incloses en aquest article s'emmarquen en la reflexió metodològica duta a terme per el grup d'investigació consolidat LICEC (referència 2014SGR1492) per AGAUR i finançat per el Ministerio de Economía y Competitividad (referència EDU2015-66643-C2-1-P).

\section{REFERÈNCIES.}

BALDAIA, L. (2006). El cambio en las concepciones didácticas sobre las prácticas, en la enseñanza de la biología. Alambique, Didáctica de las Ciencias Experimentales, 47, 23-29.

BAROLLI, E., LABURÚ, C.E., GURIDI, V.M. (2010). Laboratorio didáctico de ciencias: caminos de investigación. Revista Electrónica de Enseñanza de las Ciencias, 9 (1), 88-110.
BESSON, I., DOMÈNECH-CASAL, J., GOYTIA, E., SÁNCHEZ, N. (2012). EduWikiLab: la creació d'un espai col•laboratiu sobre treballs pràctics al laboratori $i$ al taller. Revista Ciències (2012) 23, 15-20.

BESSON, I., GOYTIA, E., MIRÓ, M., DOMÈNECHCASAL, J. (2015). Pràctiques mudes, congressos científics, seminaris de recerca $i$ altres dinàmiques científiques d'oralitat al laboratori $i$ a l'aula. Revista Ciències, 29, 15-24.

BLOOM, B. S., ENGELHART, M. D., FURST, E. J., HILL, W. H., KRATHWOHL, D. R. (1956). Taxonomy of educational objectives: The classification of educational goals. Handbook I: Cognitive domain. New York: David McKay Company.

CAAMAÑO, A. (1992). Los trabajos prácticos en ciencias experimentales. Una reflexión sobre sus objetivos y una propuesta para su diversificación. Aula de Innovación Educativa, 9, 61-68.

CAAMAÑO, A. (2002). ¿Cómo transformar los trabajos prácticos tradicionales en trabajos prácticos investigativos? Aula de Innovación Educativa, 113, 21-26.

CAAMAÑ̃, A. (2004). Experiencias, experimentos ilustrativos, ejercicios prácticos e investigaciones: Una clasificación útil de los trabajos prácticos? Alambique, Didáctica de las Ciencias Experimentales, 39, 8-19.

CAAMAÑO, A. (2012) ¿Cómo introducir la indagación en el aula? Los trabajos prácticos investigativos. Alambique: didáctica de las ciencias experimentales, 70, 83-91.

COUSO, D. (2014). De la moda de "aprender indagando" a la indagación para modelizar: una reflexión crítica. XXVI Encuentro de Didáctica de las Ciencias Experimentales. Huelva (Andalucía).

DEPARTAMENT D'ENSENYAMENT (2015). Decret 187/2015, d'ordenació dels ensenyaments de l'educació secundària obligatòria. Diari Oficial de la Generalitat de Catalunya, 6945, 1-305.

DOMĖNECH, X., LLORENTE, I., RUIZ, N., SERRA, C., ULLDEMOLINS, M., ARRIZABALAGA, A., DOMĖNECH-CASAL, J. (2016). XYZ-Stars $i$ Solar System Pathway: una experiència museística de treball per projectes sobre les cons- 
tel•lacions $i$ el Sistema Solar. Revista Ciències 31, 21-28.

DOMÈNECH-CASAL, J. (2013a). Escritura de artículos y diseño de experimentos: andamios para escribir, pensar y actuar en el laboratorio. Enseñanza de las Ciencias, número especial. Congreso ENSE Ciencias, 1085-1089.

DOMÈNECH-CASAL, J. (2013b). Secuencias de apertura experimental y escritura de artículos en el laboratorio: un itinerario de mejora de los trabajos prácticos en el laboratorio. Enseñanza de las Ciencias, 31 (3), 249-262.

DOMÈNECH-CASAL, J. (2014). Indagación en el aula mediante actividades manipulativas y mediadas por ordenador. Alambique, Didáctica de las Ciencias Experimentales 76, 17-27.

DOMÈNECH-CASAL, J. (2016a). Proyecto C3: indagación científica, lengua y contextos en la ESO. Aula de Secundaria, 19, 15-19.

DOMÈNECH-CASAL, J. (2016b). "Drug Research": una secuencia contextualizada de indagación sobre mitosis, cáncer y creación del conocimiento científico. Investigación en la escuela, 88, 1-19.

GARRIDO, A., SIMARRO, C. (2014). El nou marc d'avaluació de la competència científica PISA 2015: Revisió i reflexions didàctiques. Revista Ciències 28, 21-26.

GOYTIA, E., BESSON, I., GASCO, J., DOMÈNECH-CASAL, J. (2015a). Evaluar habilidades científicas. Indagación en los exámenes. ¿Una vía para cambiar la práctica didáctica en el aula? Alambique, Didáctica de las Ciencias Experimentales 79 .

GOYTIA, E., BESSON, I., DOMÈNECH-CASAL, J. (2015b). Protocol TestingScienceSkills: una eina senzilla per a dissenyar preguntes d'examen per a l'avaluació de les habilitats científiques de l'alumnat. Revista Ciències, 30, 20-28.

HODSON, D. (1994). Hacia un enfoque más crítico del trabajo de laboratorio. Enseñanza de las Ciencias 12(3), 299-313.

JORBA, J. , GÓMEZ, I., PRAT, A. (1998). Parlar $i$ escriure per aprendre. Barcelona: Institut de Ciències de l'Educació.
LLEWELLYN, D. (2005). Teaching High School Science through Inquiry: A case study approach. Corwin Press \& NSTA press.

LLORENTE, I., DOMÈNECH, X., RUIZ, N., SELGA, I., SERRA, C., DOMÈNECH-CASAL, J. (en avaluació). 1st Earth's Fluids Congress: una experiencia de trabajo por Proyectos de Investigación mediante dos Niveles Didácticos. Comunicación y Pedagogía, en avaluació.

MENOYO, M.P. (2010). ;Yo me apunto a hacer trabajos de investigación! La voz del profesorado y el alumnado. Aula de Innovación Educativa, 195, 56-62

MINISTERIO DE EDUCACIÓN, CULTURA Y DEPORTE (2015). Currículum de Biología y Geología, 4ํ de ESO. Real Decreto 1105/2014, de 26 de diciembre, por el que se establece el currículo básico de la Educación Secundaria Obligatoria y del Bachillerato. Boletín Oficial del Estado, A-2015-37, 211-213.

NATIONAL RESEARCH COUNCIL (2012). A Framework for K-12 Science Education: Practices, Crosscutting Concepts, and Core Ideas. Committee on Conceptual Framework for the New K12 Science Education Standards; National Research Council, National Academy of Sciences, USA.

OCDE (2013). PISA 2015. Draft Science Framework.

[http://www.oecd.org/pisa/pisaproducts/Draft PISA 2015 Science Framework .pdf] Consultat $15 / 03 / 2015$

OSBORNE, J., DILLON, J. (2008). Science Education in Europe: Critical Reflections. Report to the Nuffield Foundation.

MERINO, C., IZQUIERDO, M. (2011). Aportes a la modelización según el cambio químico. Educación química, 22(2), 212-223

SANMARTÍ, N. (coord). (2003) Aprendre ciències tot aprenent a escriure ciència. Barcelona: Edicions 62.

SANMARTÍ, N., MÁRQUEZ, N. (2012). Enseñar a plantear preguntas investigables. Didáctica de las Ciencias Experimentales, 70, 27-36.

TENREIRO-VIEIRA， C., MARQUÉS-VIEIRA, R. (2006). Diseño y validación de actividades de 
laboratorio para promover el pensamiento crítico de los alumnos. Revista Eureka de Enseñanza y Divulgación de las Ciencias 3 (3), 452-466.

VIENNOT, L. (2011). Els molts reptes d'un ensenyament de les Ciències basat en la indagació: ens aportaran múltiples beneficis en l'aprenentatge? Revista Ciències 18, 22-36.

\section{NOTES.}

[1] Projecte C3, Creació del Coneixment Científic: https://sites.google.com/a/xtec.cat/c3/home (Domènech-Casal, 2016a)

[2] Dins les seqüències ECBI podríem diferenciar les indagacions obertes (aquelles en què l'aprenent es planteja un tema i pregunta de la seva elecció i les metodologies), les indagacions estructurades (en les que el docent delimita d'alguna manera-materials, preguntes inicials,...l'abast o direcció del procés investigador, mantenint aspectes a decisió del l'alumne/a) o les indagacions tancades (on tots els processos de la recerca són pautats i preestablerts per el docent -pregunta, metodologies, etc...). (Caamaño, 1992).

[3] Taula de desenllaços per a dissenyar experiments:

https://www.box.com/s/cj8hxduzzs83xi50fl71

[4] Plantilla per a l'escriptura d'articles científics escolars:

https://app.box.com/s/y6cdza87o2iownxs4ag5

[5] Llista de comprovació per a l'auto i co-avaluació d'articles científics escolars descarregable a: https://app.box.com/s/u26osnc2uap6oj9xf24wyr 9rnuyhe4si

[6] Totes les bastides lingüístiques són disponibles a la web del ProjecteC3:

https://sites.google.com/a/xtec.cat/c3/home

[7] Plataforma col-laborativa EduWikiLab de pràctiques de laboratori:

http://eduwikilab.wikispaces.com/ 